\title{
Incidence of Human Immunodeficiency Virus in Sickle Cell Patients in the Cape Coast Metropolis, Ghana
}

\author{
Amaris T. D. Baah1, Daniel E. Azumah², Charles Ampiah², Johnson Boampong1, \\ Samuel V. Nuvor ${ }^{1,3^{*}}$ \\ ${ }^{1}$ Department of Biolomedical and Forensic Sciences, School of Biological Sciences, University of Cape Coast, \\ Cape Coast, Ghana \\ ${ }^{2}$ Central Regional Teaching Hospital, Cape Coast, Ghana \\ ${ }^{3}$ Department of Microbiology, School of Medical Sciences, University of Cape Coast, Cape Coast, Ghana \\ Email: s.v.nuvor@uccsms.edu.gh
}

Received 22 June 2014; revised 20 July 2014; accepted 15 August 2014

Copyright (C) 2014 by authors and Scientific Research Publishing Inc.

This work is licensed under the Creative Commons Attribution International License (CC BY).

http://creativecommons.org/licenses/by/4.0/

(c) (i) Open Access

\begin{abstract}
Context: Human immunodeficiency virus (HIV) is a well-known pathogen that causes acquired immunodeficiency syndrome (AIDS). The course of HIV infection and progression may be influenced by sickle cell traits. Objectives: The aim of this study was to determine the incidence of HIV among sickle cell patients in the Cape Coast metropolis. Methods: A cross sectional study was conducted among patients who visited the Central Regional Hospital, Cape Coast. About $2 \mathrm{ml}$ of blood sample was drawn from each participant for sickle cell test using sodium metabisulphite solution. Sickle cell positive samples were selected and tested for the presence of HIV using Alere Determine $^{\mathrm{TM}}$ HIV-1/2. Results: A total of 75 patients made up of 25 males and 50 females were enrolled. Their age ranges between 4 to 59 years $(27,1$ - 15 years; 24, 16 - 30 years; 17, 31 - 45 years; 7, 46 - 60 years). Fifteen (15) $(20 \%)$ had received at least a single blood transfusion while the remaining 60 $(80 \%)$ had never received blood transfusion before the study. Thirty-six patients $(48.0 \%)$ were married and the other 39 patients $(52.0 \%)$ were single. Five patients $(6.7 \%)$ had antibodies to HIV whereas 70 patients $(93.3 \%)$ were not with the virus. Conclusion: The incidence rate of HIV among sickle cell trait children and the youths of Cape Coast metropolis were found to be $6.7 \%$. This may suggest that sickle cell traits in children and the youth may be associated with HIV transmission.
\end{abstract}

\section{Keywords}

HIV, Sickle Cell Disease, Incidence, Prevalence

\footnotetext{
${ }^{*}$ Corresponding author.

How to cite this paper: Baah, A.T.D., Azumah, D.E., Ampiah, C., Boampong, J. and Nuvor, S.V. (2014) Incidence of Human Immunodeficiency Virus in Sickle Cell Patients in the Cape Coast Metropolis, Ghana. World Journal of AIDS, 4, 338-345. http://dx.doi.org/10.4236/wja.2014.43040
} 


\section{Introduction}

Human immunodeficiency virus (HIV) infection has remained a serious health problem in the world, even though there has been a decline in the world prevalence rates. Currently, there has been 33\% reduction in HIV infection to about 2.3 million in 2012, since 2001 and AIDS-related deaths had also dropped by 30\% from the peak in 2005 [1]. These have occurred as a result of the accessibility to anti-retroviral treatment that has improved the life of many infected people.

In Ghana, HIV prevalence has also declined from 3.6\% to 1.3\% in 2012 [1] [2]. These are indication of global effort in controlling HIV infection. However, the infection is high in some areas in the country. The Eastern region has for long time been the highest HIV prevalent region but in recent times the Central region has now become the region with the highest HIV prevalence in the country. According to the 2011 HIV Sentinel Surveillance Report, the Central Region recorded HIV prevalence of 4.7\%, while the Eastern Region registered 3.6\% prevalence [2]. Whereas the Central Region assumed the leading HIV prevalence position, Cape Coast, the regional capital, has also taken over from Agomanya in the Eastern Region as the epicentre of AIDS in Ghana. Cape Coast serves as an urban surveillance site and recorded the highest HIV prevalence of 9.6\% in 2011 [2].

The devastating effect of the HIV on the immune system has led to the successful establishment of other opportunistic infections and there are several diseases which are generally not harmful but have been able to cause fatality due to the destruction of the immune system by HIV [3]. Also the effect of HIV on people with genetic defect condition such as Sickle Cell Anaemia has been documented [4] [5]. However, studies of the prevalence and the effect of HIV on Sickle Cell Anemia subjects have not been well elucidated. A few studies conducted suggested that HIV infection progresses slowly in patients with sickle cell disease (SCD) [6]-[8]. Further studies have also revealed that Sickle Cell trait patients are associated with low frequency of HIV diagnosis [9]. A study of HIV infection through blood transfusion in children with Sickle Cell Anaemia in Nigeria and Congo were 2.9\% and $2.6 \%$ respectively [10] [11]. Based on these observations, some concerns have been raised as to whether the sickle cell disease protect against the acquisition of HIV.

The sickle cell disease is a genetic disorder that is characterized by a chronic Anaemia occurring almost exclusively in individuals of African descent [12]. Because patients with Sickle Cell disease lack enough red blood cells for life sustenance they require frequent blood donation. They are therefore susceptible to blood borne infections such as malaria, hepatitis B, hepatitis C and HIV [13] [14]. Although some studies had been carried out on Sickle Cell diseases and the relationship with malaria and hepatitis in Ghana [15]-[17] documentation on the prevalence of HIV among Sickle Cell subjects is limited. This study aims at determining the incidence of human immunodeficiency virus (HIV) among Sickle Cell patients in the Cape Coast metropolis. We also compared the demographic features such as age, sex, marital status, blood transfusion history and their sickle hemoglobin gene groupings.

\section{Methods}

\subsection{Background of Study Area}

This work was carried out at the Central Regional Hospital, Interberton, in the Cape Coast Metropolis, Ghana; West Africa. The Central Regional Hospital is a government hospital which serves almost every town in the region especially the Cape Coast Township which includes Abura, Pedu, Ekon, Nkanfoa, Kakomdo, Effutu, Ankaful, Kwaprow, Amamoma, Essuekyir, Akotokyere, Anto Esuakyir, among others. The Central Regional’s capital, Cape Coast, is located between latitude $5^{\circ} 5^{\prime \prime} \mathrm{N}$ and longitude $1^{\circ} 15^{\prime \prime} \mathrm{W}$ on the Greenwich Meridian. It is bordered by Komenda Edina Eguafo Abirem (KEEA) District to the west, Twifo Heman Lower Denkyira District to the east Abura Asebu Kwamankese district to the north and Gulf of Guinea to the south. The main occupation of this locality is fishing, farming and trading.

\subsection{Study Design}

A cross sectional study was employed in this research. Personal data such as age, sex, history of blood transfusion and marital status were obtained randomly from consented patients through structured questionnaires. Inclusion criteria were patients with haemoglobin phenotype SS, SC and AS. Exclusion criteria were patients with haemoglobin phenotype AA. 


\subsection{Sample Collection}

Two milliliters (2 ml) of blood was drawn from patients into Ethylene Diamine Tetraaceticacid (EDTA) anticoagulant tubes for sickling test on the same day. Blood samples that tested positive to sickling were selected and centrifuged after which the plasma were aspirated into new EDTA tubes and stored at a temperature of $4{ }^{\circ} \mathrm{C}$ for later analysis of HIV infection. The sickling status of each sample was determined by adding 1 to 2 drops of sodium metabisulphite solution (sickling fluid) to each slide containing a drop of blood sample. The sickling fluid was mixed thoroughly with the blood to get a homogenous mixture. A cover slip was then applied gently avoiding bubbles, and this was allowed to stand for about an hour. After the stipulated time, the slides were examined under a light microscope for sickled red blood cells. The blood of sickling positive samples were then selected and centrifuged. The plasma of each centrifuged blood was pipetted into fresh EDTA tubes and stored at $4^{\circ} \mathrm{C}$. After some time, the stored plasma was tested for the presence of HIV using Alere Determine ${ }^{\mathrm{TM}} \mathrm{HIV}-1 / 2$. Three drops of plasma was added to the sample pad of the kit. This was repeated for all the 75 sickling positive samples. Results obtained were recorded and analyzed. The Alere Determine ${ }^{\mathrm{TM}} \mathrm{HIV}-1 / 2$ is an in-vitro, visually read, qualitative immunoassay that detects antibodies to HIV-1 and HIV-2 in human serum, plasma or whole blood. The biological principle behind this procedure is that Alere Determine ${ }^{\mathrm{TM}} \mathrm{HIV}-1 / 2$ is an immunochromatographic test that has a conjugate or sample pad through which the plasma migrates. The plasma reconstitutes and mixes with the selenium colloid-antigen conjugate. The mixture formed continues to migrate through the solid phase to the antigen immobilized recombinant antigens and synthetic peptides at the patient window site. If antibodies to HIV-1 and/or HIV-2 are present in the sample, the antibodies bind to the antigen-selenium colloid and to the antigen at the patient window, forming a red line at the patient window site. However, if antibodies to HIV-1 and/or HIV-2 are absent, the antigen-selenium colloid flows past the patient window site, and no red line was formed.

\subsection{Statistical Analysis}

Statistical package for Social Science software (SPSS Version 17 Inc., Chicago) and Graphpad Prism 3 was used in analyzing the results. Frequency distributions were performed and non-parametric Chi-square was used to test association between categorical variables. $\mathrm{p}$ value $<0.05$ was considered to be statistically significant.

\section{Results}

A total of 75 sickle cell patients were used in the study. Among these 25 were males which was significantly lower than 50 females ( $p=0.004$, Table 1). Also, 39 of the patients were married. Again, twenty-seven (27) patients were between the ages of 1 - 15 years; 24, between the ages of 16 - 30 years; 17, between the ages of 31 45 years and 7, between the ages of 46 - 60 years. The age group of $1-15,16-30,31$ - 45 years were significantly different from 46 - 60 years $(\mathrm{p}=0.002)$. This means many of the sickle cell patients were youth and active. There were 15 patients who had received transfusion at least once as against 60 patients who had never been transfused before at the time of the study $(p=0.001)$. In addition, sickle cell patients with genotype AS, SS and SC were 38, 5 and 32 respectively indicating that significant number of the sickle cell patients were carriers $(p=0.001)$. Furthermore, patients who were positive to HIV were 5 with a prevalence rate of $6.7 \%$ and were significantly lower $(\mathrm{p}=0.001)$ than HIV uninfected Sickle Cell patients.

HIV incidence was found among different sickling genotypes groups of the sickle cell patients. Table 2 showed that out of 70 (93.3\%) patients that tested negative to HIV, 35 (46.6\%) were sickle cell patients with haemoglobin genotype AS, 5 (6.7\%) with haemoglobin genotype SS and 30 (42.9\%) with haemoglobin genotype SC. However, 3 (4.0\%) of those HIV positive patients were with the haemoglobin genotype AS while 2 (2.7\%) were of the genotype SC; no sickle cell patient with the genotype SS tested positive to HIV. Also, there was no significant relationship between sickling status and HIV infection ( $\mathrm{p}=0.795)$.

The incidence of HIV among different age categories was analysed. The results showed that 70 (93.3\%) of patients tested negative to HIV (Table 3). Out of which 24 (32.0\%) were within the age group 1 - 15 years whereas 22 (29.3\%) were within the 16 - 30 years age group. Again, 17 (22.7\%) were within the age grouped 31 - 45 years whereas 7 (9.3\%) were within the age grouped 46 - 60 years. For HIV incidence, 5 (6.7\%) were positive, out of these $3(4.0 \%)$ were within the age category 1 - 15 years and $2(2.7 \%)$ within the age category 16 - 30 years. Age groups 31 - 45 and 46 - 60 years recorded no positive cases of HIV. There was no significant difference in the prevalence of HIV among age groups $(\mathrm{p}>0.05)$. 
Table 1. Gender, age and background information of participants.

\begin{tabular}{|c|c|c|c|c|}
\hline Variables & $\mathbf{N}$ & $(\%)$ & p-value & Chi-square $\left(\mathrm{X}^{2}\right)$ \\
\hline \multicolumn{5}{|l|}{ Gender } \\
\hline Males & 25 & 33.3 & 0.004 & 8.333 \\
\hline Females & 50 & 66.7 & & \\
\hline \multicolumn{5}{|l|}{ Age (years) } \\
\hline $1-15$ & 27 & 36 & 0.002 & 15.241 \\
\hline $16-30$ & 24 & 32 & & \\
\hline $31-45$ & 17 & 22.7 & & \\
\hline $46-60$ & 7 & 9.3 & & \\
\hline \multicolumn{5}{|c|}{ Marital status } \\
\hline Single & 39 & 53.3 & 0.599 & 0.276 \\
\hline Married & 36 & 46.7 & & \\
\hline \multicolumn{5}{|l|}{ HBT } \\
\hline Yes & 15 & 20 & 0.001 & 27.74 \\
\hline No & 60 & 80 & & \\
\hline \multicolumn{5}{|c|}{ Sickling genotype } \\
\hline AS & 38 & 50.7 & 0.001 & 24.72 \\
\hline SS & 5 & 6.7 & & \\
\hline SC & 32 & 42.7 & & \\
\hline \multicolumn{5}{|l|}{ HIV status } \\
\hline Positive & 5 & 6.7 & 0.001 & 56.333 \\
\hline Negative & 70 & 93.3 & & \\
\hline
\end{tabular}

N: frequency; HBT: History of blood transfusion. p value $<0.05$ is statistically significant

Table 2. Incidence of HIV in different sickling genotypes.

\begin{tabular}{|c|c|c|c|c|c|c|}
\hline & & & \multicolumn{3}{|c|}{ Sickling genotype } & \multirow{2}{*}{ Total } \\
\hline & & & AS & SS & SC & \\
\hline \multirow{4}{*}{ HIV status } & & Count & 35 & 5 & 30 & \\
\hline & & $\%$ of Total & $46.6 \%$ & $6.7 \%$ & $40.0 \%$ & $93.3 \%$ \\
\hline & & Count & 3 & 0 & 2 & \\
\hline & Positive & $\%$ of Total & $4.0 \%$ & $0.0 \%$ & $2.7 \%$ & $6.7 \%$ \\
\hline \multicolumn{2}{|l|}{ Total } & $\begin{array}{c}\text { Count } \\
\% \text { of Total }\end{array}$ & $\begin{array}{c}38 \\
50.7 \%\end{array}$ & $\begin{array}{c}5 \\
6.7 \%\end{array}$ & $\begin{array}{c}32 \\
42.7 \%\end{array}$ & $\begin{array}{c}75 \\
100.0 \%\end{array}$ \\
\hline
\end{tabular}

Chi-square $\left(X^{2}\right)=0.458 ; p=0.795$.

In Table 4, the relationship between marital status and HIV were determined. Out of the 70 (93.3\%) patients that tested negative to HIV, 36 (48.0\%) were single and the remaining 34 (45.3\%) were married. Also, 3 (4.0\%) out of $5(6.7 \%)$ were single patients that tested positive to HIV; the remaining 2 (2.7\%) were married people. 
Table 3. Incidence of HIV among different age categories.

\begin{tabular}{|c|c|c|c|c|c|c|c|}
\hline & & & \multicolumn{4}{|c|}{ Age (years) } & \multirow{2}{*}{ Total } \\
\hline & & & $1-15$ & $16-30$ & $31-45$ & $46-60$ & \\
\hline \multirow{4}{*}{ HIV status } & \multirow{2}{*}{ Negative } & Count & 24 & 22 & 17 & 7 & \\
\hline & & $\%$ of Total & $32.0 \%$ & $29.3 \%$ & $22.7 \%$ & $9.3 \%$ & $93.3 \%$ \\
\hline & \multirow{2}{*}{ Positive } & Count & 3 & 2 & 0 & 0 & \\
\hline & & $\%$ of Total & $4.0 \%$ & $2.7 \%$ & $0.0 \%$ & $0.0 \%$ & $6.7 \%$ \\
\hline \multirow{2}{*}{\multicolumn{2}{|c|}{ Total }} & Count & 27 & 24 & 17 & 7 & 75 \\
\hline & & $\%$ of Total & $36.0 \%$ & $32.0 \%$ & $22.7 \%$ & $9.3 \%$ & $100.0 \%$ \\
\hline
\end{tabular}

Chi-square $\left(\mathrm{X}^{2}\right)=2.679 ; \mathrm{p}=0.444$.

Table 4. Relationship between marital status and HIV infection.

\begin{tabular}{|c|c|c|c|c|c|}
\hline & & & \multicolumn{2}{|c|}{ Marital status } & \multirow{2}{*}{ Total } \\
\hline & & & Single & Married & \\
\hline \multirow{4}{*}{ HIV status } & \multirow{2}{*}{ Negative } & Count & 36 & 34 & \\
\hline & & $\%$ of total & $48.0 \%$ & $45.3 \%$ & $93.3 \%$ \\
\hline & \multirow{2}{*}{ Positive } & Count & 3 & 2 & \\
\hline & & $\%$ of Total & $4.0 \%$ & $2.7 \%$ & $6.7 \%$ \\
\hline \multirow{2}{*}{\multicolumn{2}{|c|}{ Total }} & Count & 39 & 36 & 75 \\
\hline & & $\%$ of Total & $52.0 \%$ & $48.0 \%$ & $100.0 \%$ \\
\hline
\end{tabular}

Chi-square $\left(\mathrm{X}^{2}\right)=0.137 ; \mathrm{p}=0.711$.

There was no significant differences in marital status of subjects who were HIV positive $(\mathrm{p}=0.711)$.

The relationship between blood transfusion and HIV infection were also determined (Table 5). For 70 (93.3\%) HIV negative patients, 55 (73.3\%) had not been transfused with blood whereas 15 (20.0\%) have been transfused with donors blood. On the other hand, 5 (6.7\%) of the HIV positive individuals had never received blood transfusion before the study. Therefore there was no significant association between blood transfusion and HIV infection $(\mathrm{p}=0.247)$.

In Table 6, the relationship between gender and HIV infection were also analysed. Those who were negative to HIV were 47 (62.7\%) females and 23 (30.6\%) males. Also, those who tested positive to the virus included 3 (4.0\%) females and 2 (2.7\%) males. There was statistically no significance differences of HIV infection among the females and males $(\mathrm{p}=0.703)$.

\section{Discussion}

This study showed that some sickle cell patients in Cape Coast municipality are infected with HIV and the incidence rate was found to be $6.7 \%$. This could support the studies of some researchers which suggested that HIV infection progresses slowly in patients with sickle cell disease (SCD) [6] [9]. SCD is associated with upregulated inflammatory and haemolytic pathways which lead to the suggestion that the disease may influence the course of HIV infection and progression [6] [8]. However, Nouraie et al. (2012) reported 1.5\% HIV diagnosis in adult African Americans with sickle cell diseases as against 3\% in those without disease [18]. It may be possible that the lower risk of HIV co-morbidity with SCD may present a unique effect that alters the risk of HIV infection or progression. However, it cannot therefore be doubted that infection with viruses such as the human immunodeficiency virus is highly fatal and thus the least incidence is of great concern to the metropolis and the nation at large.

The study revealed that the number of females that were sickle cell positive was twice the number of males. 
Table 5. Relationship between blood transfusion and HIV infection.

\begin{tabular}{|c|c|c|c|c|c|}
\hline & & & \multicolumn{2}{|c|}{ Blood transfusion } & \multirow{2}{*}{ Total } \\
\hline & & & No & Yes & \\
\hline \multirow{4}{*}{ HIV status } & \multirow{2}{*}{ Negative } & Count & 55 & 15 & \\
\hline & & & $73.3 \%$ & $20.0 \%$ & $93.3 \%$ \\
\hline & \multirow{2}{*}{ Positive } & Count & 5 & 0 & \\
\hline & & $\%$ of Total & $6.7 \%$ & $0.0 \%$ & $6.7 \%$ \\
\hline \multirow{2}{*}{\multicolumn{2}{|c|}{ Total }} & Count & 60 & 15 & 75 \\
\hline & & $\%$ of Total & $80.0 \%$ & $20.0 \%$ & $100.0 \%$ \\
\hline
\end{tabular}

Chi-square $\left(\mathrm{X}^{2}\right)=1.339 ; \mathrm{p}=0.247$.

Table 6. Relationship between gender and HIV infection.

\begin{tabular}{|c|c|c|c|c|c|}
\hline & & & \multicolumn{2}{|c|}{ Gender } & \multirow{2}{*}{ Total } \\
\hline & & & Female & Male & \\
\hline \multirow{4}{*}{ HIV status } & \multirow{2}{*}{ Negative } & Count & 47 & 23 & \\
\hline & & $\%$ of Total & $62.7 \%$ & $30.6 \%$ & $93.3 \%$ \\
\hline & \multirow{2}{*}{ Positive } & Count & 3 & 2 & \\
\hline & & $\%$ of Total & $4.0 \%$ & $2.7 \%$ & $6.7 \%$ \\
\hline \multirow{2}{*}{\multicolumn{2}{|c|}{ Total }} & Count & 50 & 25 & 75 \\
\hline & & $\%$ of Total & $66.7 \%$ & $33.3 \%$ & $100.0 \%$ \\
\hline
\end{tabular}

Chi-square $\left(\mathrm{X}^{2}\right)=0.107 ; \mathrm{p}=0.703$.

This was due to the fact that more females participated in the study than the males. The notion that more females attend hospitals compare to their male counterparts is prominent in the Cape Coast metropolis and would have contributed to this effect. In addition, the highest number of participants in the study was within the age group 1 15 years and the lowest number within the age group 46 - 60 years. This suggests that sickle cell disease may be common in children than in adults and also the incidence of HIV occurred in the age group 1 - 30 years which may mainly be children and the youth. Thus HIV was more common in children and the youth than in the elderly in the Cape Coast community. This is in consistent with CDC report, which noted the largest percentage of HIV infections occurred in the youth and children [19]. This is usually the case when mother-to-child HIV transmission is common and pregnant mothers do not take their antiretroviral therapy during pregnancy [7] [20].

Majority of the sickle cell patients that participated in the study had genotype AS and SC and 5 of them were infected with HIV. Sickle cell trait may provide a survival advantage over people with normal hemoglobin in regions where malaria is endemic [21] [22]. However, whether the trait also protects the individuals from HIV infection is not yet known. These groups of sickle cell traits are careers of the trait and are clinically healthy [23] It is likely that their life style might have exposed them to infection and further studies with larger number of HIV infected subjects with sickle cell trait will give a clear relationship of the condition and HIV infection.

There was similar number of both married and unmarried sickle cell patients involved in the study who was infected with HIV. This is an indication that HIV transmission in the Cape Coast municipality may not be only associated with the unmarried individuals who may be indulging in sexual promiscuity. It could be likely that married couples might have multiple sexual partners as well which is likely to expose them to the HIV infection.

Also, the number of those who had received at least a single blood transfusion was not infected with HIV but rather those without blood transfusion were infected with HIV. It may suggest that blood transfusion may not be a risk factor of HIV infection in the Cape Coast Community. The observation confirm report from some health services which states the risk of acquiring HIV from a blood transfusion is very low due to the fact that blood 
and organ banks screen out most potential donors at risk for HIV infection in advance [24]. It therefore indicated that sexual transmission and mother-to-child transmission of HIV may be common in the Cape Coast metropolis. This is in consistence with HIV sentinel survey report of Ghana Aids Commission (GAC) which indicated the highest prevalence (9.6\%) of HIV recorded in Cape Coast [2]. It was suggested that high HIV rate in Cape Coast can be attributed to the influx of young, healthy migrant workers in the oil field from the Western Region to the Central Region. These people are said to be promising the youth in getting them employment in the oil field. They therefore befriend them and in most cases may indulge in sexual activities resulting in the spread of sexually transmitted diseases including HIV. Besides, many residents are mired in poverty and have endured intermittent food insecurity. Conditions such as these invariably increase sexual vulnerability and enhance sex works, both of which tend to increase HIV transmission in the region.

\section{Conclusion}

HIV infection is found among Sickle Cell patients who are mainly children and youth in Cape Coast municipality. This may indicate that HIV infections is common in the Sickle Cell traits youth and may follow a long pattern of disease progression thereby contributing to the spread of the disease among the youth.

\section{Acknowledgements}

We appreciate the contribution of Mr. Eric Djan and Mr. Ernest Asiamah on carrying out the study. Our sincere thanks go to Mr. Koffie for assisting in statistical analysis of the data. We also thank the Dean of School of Biological Sciences, University of Cape Coast for supporting the study.

\section{References}

[1] UNAIDS (2013) UNAIDS Reports on the Global AIDS Epidemic 2013. www.unaids.org/en/media/unaids/contentassets/documents/epidemiology/2013/UNAIDS_G

[2] GAC (2012) Central Region Tops HIV Prevalence in Ghana. Ghana Aids Commission. www.gbcghana.com

[3] Martinez, J. and Temesgen, Z. (2006) Opportunistic Infections in Patients with HIV and AIDS. Fungal and Parasitic Infections. Le Journal Medical Libanais, 54, 84-90.

[4] Jenerette, C.M. and Brewer, C. (2010) Health-Related Stigma in Young Adults with Sickle Cell Disease. Journal of the National Medical Association, 102, 1050-1055.

[5] Bagasra, O., Steiner, R.M., Ballas, S.K., Castro, O., Dornadula, G., Embury, S., Jungkind, D., Bobroski, L., Kutlar, A. and Burchott, S. (1998) Viral Burden and Disease Progression in HIV-1-Infected Patients with Sickle Cell Anemia. American Journal of Hematology, 59, 199-207. http://dx.doi.org/10.1002/(SICI)1096-8652(199811)59:3<199::AID-AJH4>3.0.CO;2-L

[6] Castro, O., Saxinger, C., Barnes, S., Alexander, S., Flagg, R., et al. (1990) Prevalence of Antibodies to Human Immunodeficiency Virus and to Human T Cell Leukemia Virus Type I in Transfused Sickle Cell Disease Patients. The Journal of Infectious Diseases, 162, 743-745. http://dx.doi.org/10.1093/infdis/162.3.743

[7] Emodi, I.J. and Okafor, G.O. (1998) Clinical Manifestations of HIV Infection in Children at Enugu, Nigeria. Journal of Tropical Pediatrics, 44, 73-76. http://dx.doi.org/10.1093/tropej/44.2.73

[8] Sellier, P., Masson, E., Zini, J.M., Simoneau, G., Magnier, J.D., et al. (2009) Disease Progression in HIV-1-Infected Patients Heterozygous for the Sickle Hemoglobin Gene. Aids, 23, 2362-2364. http://dx.doi.org/10.1097/QAD.0b013e32833298a7

[9] Nekhai, S., Kumari, N. and Dhawan, S. (2013) Role of Cellular Iron and Oxygen in the Regulation of HIV-1 Infection. Future Virology, 8, 301-311. http://dx.doi.org/10.2217/fvl.13.6

[10] Ubesie, A., Emodi, I., Ikefuna, A. and Ilechukwu, G. (2012) Prevalence of Human Immunodeficiency Virus Transmission among Transfused Children with Sickle Cell Anemia in Enugu Nigeria. Annals of Medical and Health Sciences Research, 2, 109-113. http://dx.doi.org/10.4103/2141-9248.105655

[11] Tshilolo, L.M., Mukendi, R.K. and Wembonyama, S.O. (2007) Blood Transfusion Rate in Congolese Patients with Sickle Cell Anemia. Indian Journal of Pediatrics, 74, 735-738. http://dx.doi.org/10.1007/s12098-007-0129-4

[12] Okpala, I. (1998) The Management of Crisis in Sickle Cell Disease. European Journal of Haematology, 60, 1-6. http://dx.doi.org/10.1111/j.1600-0609.1998.tb00989.x

[13] Ocak, S., Kaya, H., Cetin, M., Gali, E. and Ozturk, M. (2006) Seroprevalence of Hepatitis B and Hepatitis C in Patients with Thalassemia and Sickle Cell Anemia in a Long-Term Follow-Up. Archives of Medical Research, 37, 895-898. 
http://dx.doi.org/10.1016/j.arcmed.2006.04.007

[14] Ogunrinde, G.O., Keshinro, M.I. and Ige, S.O. (2005) HIV Seropositivity in Children with Sickle Cell Disease. Annals of African Medicine, 4, 104-106.

[15] Aidoo, M., Terlouw, D.J., Kolczak, M.S., McElroy, P.D., ter Kuile, F.O., Kariuki, S., et al. (2002) Protective Effects of the Sickle Cell Gene against Malaria Morbidity and Mortality. Lancet, 359, 1311-1312. http://dx.doi.org/10.1016/S0140-6736(02)08273-9

[16] Danquah, I., Ziniel, P., Eggelte, T.A., Ehrhardt, S. and Mockenhaupt, F.P. (2010) Influence of Haemoglobins S and C on Predominantly Asymptomatic Plasmodium Infections in Northern Ghana. Transactions of the Royal Society of Tropical Medicine and Hygiene, 104, 713-719. http://dx.doi.org/10.1016/j.trstmh.2010.08.001

[17] Ohene-Frimpong, K., Bonney, A., Tetteh, H. and Nkrumah, F.K. (2005) 270 Newborn Screening for Sickle Cell Disease in Ghana. Pediatric Research, 58, 401. http://dx.doi.org/10.1203/00006450-200508000-00299

[18] Nouraie, M., Nekhai, S. and Gordeuk, V.R. (2012) Sickle Cell Disease Is Associated with Decreased HIV but Higher HBV and HCV Comorbidities in US Hospital Discharge Records: A Cross-Sectional Study. Sexually Transmitted Infections, 88, 528-533. http://dx.doi.org/10.1136/sextrans-2011-050459

[19] Centers for Disease Control and Prevention CDC (2012) Estimated HIV Incidence among Adults and Adolescents in the United States, 2007-2010. HIV Surveillance Supplement Report, 4, 17.

[20] Angyo, I.A., Okpeh, E.S. and Onah, J. (1998) Paediatric AIDS in Jos, Nigeria. West African Journal of Medicine, 17, 268-272.

[21] Williams, T.N., Mwangi, T.W., Roberts, D.J., Alexander, N.D., Weatherall, D.J., Wambua, S., et al. (2005) An Immune Basis for Malaria Protection by the Sickle Cell Trait. PLoS Medicine, 2, Article ID: e128. http://dx.doi.org/10.1371/journal.pmed.0020128

[22] Williams, T.N. (2006) Human Red Blood Cell Polymorphisms and Malaria. Current Opinion in Microbiology, 9, 388-394. http://dx.doi.org/10.1016/j.mib.2006.06.009

[23] Akinbami, A.D.A., Adediran, A., Oshinaike, O., Adebola, P. and Arogundade, O. (2012) Haematological Values in Homozygous Sickle Cell Disease in Steady State and Haemoglobin Phenotypes AA Controls in Lagos, Nigeria. BMC Research Notes, 5, 396. http://dx.doi.org/10.1186/1756-0500-5-396

[24] Olaniyi, J.A., Otegbayo, J.A., Omotosho, I.A. and Olomu, O.O. (2009) Transfusion Related Hepatitis C Virus (HCV) Infection in Sickle Cell Disease Patients. African Journal of Biomedical Research, 12, 69-71. 
Scientific Research Publishing (SCIRP) is one of the largest Open Access journal publishers. It is currently publishing more than 200 open access, online, peer-reviewed journals covering a wide range of academic disciplines. SCIRP serves the worldwide academic communities and contributes to the progress and application of science with its publication.

Other selected journals from SCIRP are listed as below. Submit your manuscript to us via either submit@scirp.org or Online Submission Portal.
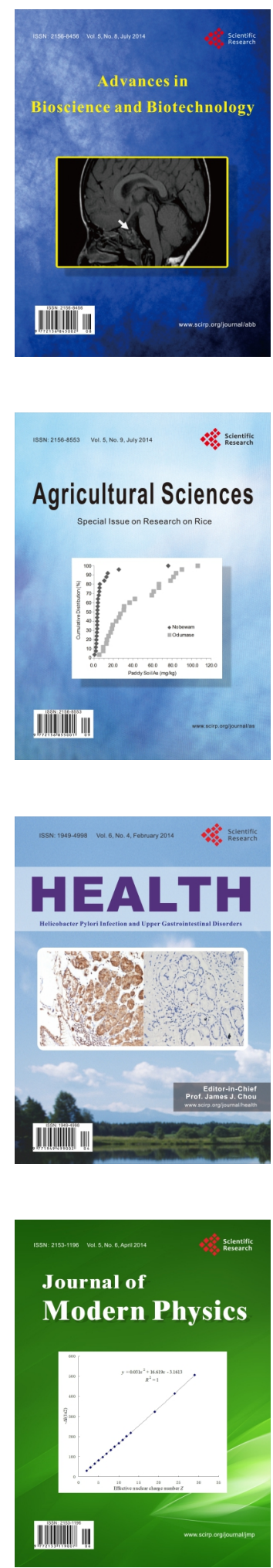
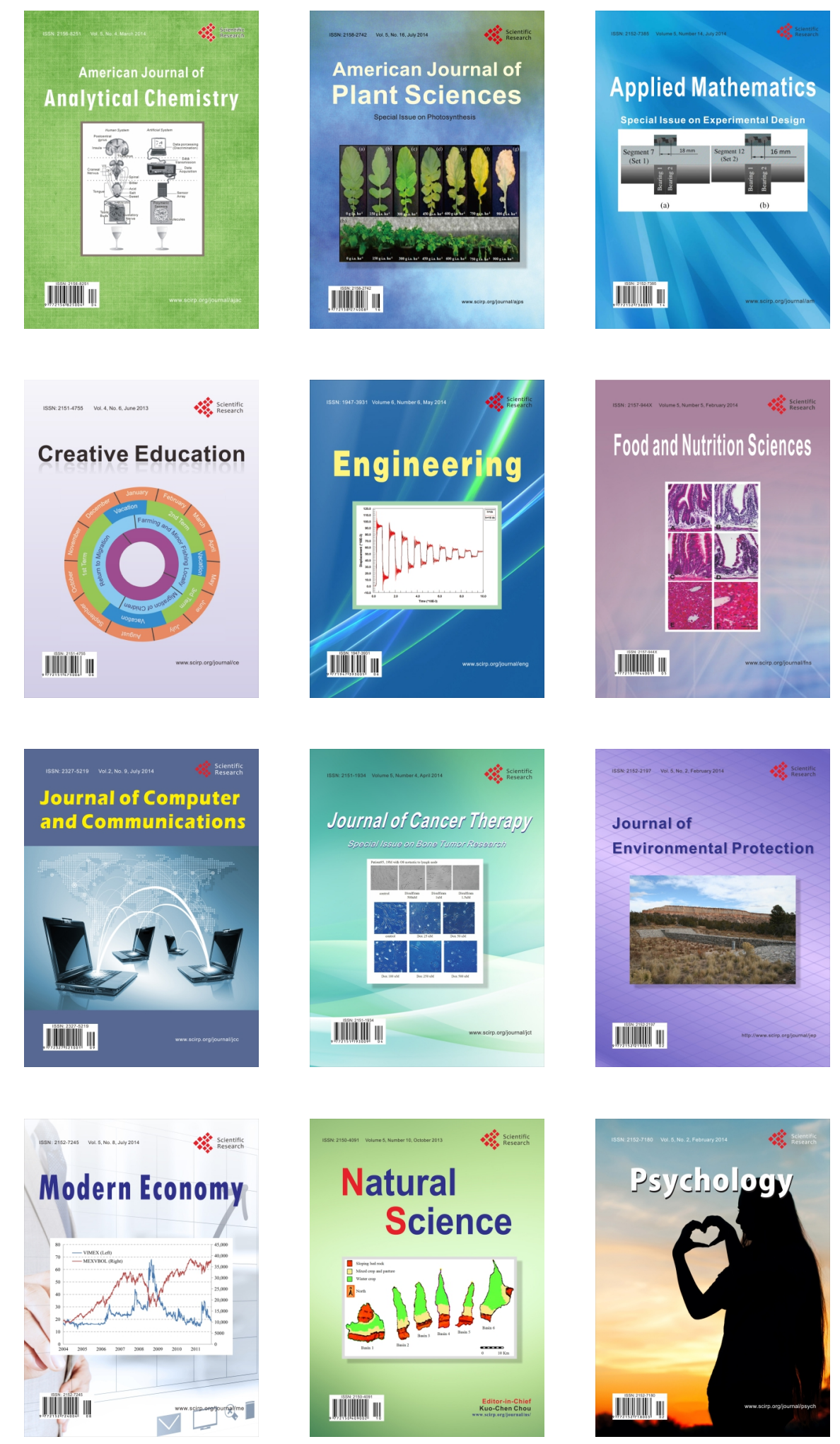